PRACTICAL ASPECTS OF ENZYME-PROBIOTICS PREPARATION SUPPLEMENTED TO QUAIL DIETS

\author{
Adel E. Abou - Zeid \\ Animal Production Department, Faculty of Agriculture, Tanta University. \\ ABSTRACT:
}

The aim of the current investigation is to demonstrate the effect of supplementing corn - soybean based diets with enzymes and probiotics preparation on quails performance. Four hundred and eighty one-day-old Japanese quail were distributed randomly to four equal experimental groups of 120 birds each. A conventional corn-soybeanmeal based diet was used. The basal diet was supplemented with three experimental feed additives. The first feed additive was Xylam ( $\beta$ xylanase, and $\alpha$ amylase), it was added at the level of $0.5 \mathrm{~g} / \mathrm{kg}$ diet. The second feed additive was Samu Biogen (Bacillus subtitles Matta, cellulase, protease, $\alpha$ - amylase, and $\beta$-amylase), it was added at the level of $0.2 \mathrm{~g} / \mathrm{kg}$ diet. The third feed additive was Organic Green Culture (Saccharomyces cerevisae, Lactobacillus acidophilus, Bacillus subtilis, Apergillus oryzae, protease, amylase, lipase, cellulase, and phytase); it was added at the level of $1.5 \mathrm{~g} / \mathrm{kg}$ diet. The results showed that Organic Green Culture supplementation increased final body weight by 13.4 while in case of Samu Biogen or Xylam increased by 8.5 and 7.1 respectively, compared with the control. Feed consumption, feed conversion ratio and mortality rate were also improved by the treatments. Organic Green Culture supplemented group had significantly higher weight of heart, thymus, spleen, and bursa compared with the control. The red blood cells (RBC's) count was significantly increased in response to Organic Green Culture followed by Samu Biogen then Xylam. The same trend was evident for white blood cells (WBC's) count. Plasma total protein, albumin and globulin were significantly increased in birds received Organic Green Culture and Samu Biogen compared to the control. Plasma aspartate aminotransferase (AST) and alanin aminotransferase (ALT) were not markedly affected by the feed additives used. Hemagglutination Inhibition titer test (HI) was significantly higher in birds received Organic Green Culture followed by birds receive Samu Biogen then birds received Xylam. The lowest bacterial count was observed with Organic Green Culture followed by Samu Biogen then Xylam supplemented group compared with the control. The same pattern was noticed with $E$. coli count. In conclusion, it is suggested that enzymes with probiotics preparations are suitable for mixing with corn- soybean based diets to improve quails performance and immunity.

Key words: Enzymes, probiotics, quail, performance and immunity.

\title{
INTRODUCTION
}

The use of enzyme and probiotic products as poultry feed supplements has attracted considerable attention by feed manufactures and poultry producers as a means of improving poultry performance. Enzymes have been used to degrade different structural carbohydrates found in cereals, particularly those that are not digested by avian and mammalian enzymes, and those that are highly viscous and have high water-binding capacity. The beneficial

Fayoum J. Agric. Res. \& Dev., Vol. 21, No. 2, July, 2007 
effects of enzyme supplementation are well documented (Sinlae and Choct, 2000 Bhat and Hazlewood, 2001, Bedford and Apajalahti, 2002, Yonemochi et al., 2003, Lazaro et al., 2004, Cowieson, 2005, Choct, 2006, Olukosi et al., 2007, and Troche et al., 2007). The enzymes have the advantage of a high specificity and the ability to operate efficiently at moderate temperature and pressure. The feed enzyme industry come into existence and it has gone through several phases of development. The first phase was the use of enzymes to enhance nutrient digestibility, focusing primarily on removing the anti-nutritive effects of non-starch polysaccharides (NSP) from diets based on viscous grains. Water-soluble $\beta$-glucans and arabinoxylans are the non starch polysaccharides (NSP) of major concern when being fed in poultry diets with high cereal grains content. $\beta$-Glucans are linear polymers of glucose with $\beta-(1.3)(1.4)$ glycosidic links while arabinoxylans consist of long backbone chains of $\beta-(1.4)$ anhydra- Dxylopyranosyl to which are attached single $\alpha$-L- arabinofuranosyl residues at the 2- or 3- position (Fincher and Stone, 1986). Enzymes allow the use of a wide range of ingredients without compromising bird performance and hence provide great flexibility in least-cost feed formulation (Ghazalah et al., 2005). Hong et al. (2002) showed that enzyme supplementation proved benefits in corn-soybean diets for ducks. Addition of enzymes lowers digesta viscosity (Bedford and Classen, 1992) and promotes feed passage rate (Salih $\boldsymbol{e t}$ al., 1991). The effectiveness of enzyme preparations are not only on the basis of growth improvement and the decrease of the feed / gain ratio (Olukosi $\boldsymbol{e t}$ al., 2007) but may also decline the number of dirty chicks as well as lower water consumption and leads in turn to better sanitary and reduction of production risk. Thus, enzymes influence the conditions in the gut and consequently the composition and activity of intestinal microflora (Preston et al., 2001).

A microbial involvement in the depression of nutrient retention in broiler has been indicated from observations that bird's performance can be improved with probiotics (Lee et al., 2007). Some efforts are underway to establish whether selective culture of $L$. acidophilus would exert inhibitory action on salmonella as well as control the enteric pathogens (Caldwell et al., 2004), and increased the birds resistance to Eimeria acervulina (Dalloul et al., 2003). It has been reported that immunological and nonimmunological defenses play a role at the intestinal mucosal surface during Eimeria invasion (Lillehoj and Trout, 1993). Dalloul et al. (2003) showed that feeding probiotics may modulate the mucosal immune system enhancing the host's resistance to enteric pathogens. Properly selected cultures of probiotics, such as lactobacillus species, can overcome those lactobacilli found in the natural flora of the birds and exert inhibitory action toward salmonella in the intestinal tract of chickens (Stern et al., 2001). Probiotics can increase nutrient utilization by providing enzymes in the gut capable of converting certain components of the diet into more digestible nutrients for the host animal. The specific function of probiotics may differ depending on the host animal and more importantly, on the characteristics of the probiotics.

Because it is thought that feedstuffs like corn and soybean that induce less viscosity may not benefit from the exogenous enzymes supplementation, thus the present study aimed to evaluate the effect of enzymes - probiotics supplementation to the corn-soybean based diet on quails performance. Moreover, to demonstrate to what extent the enzymes and probiotics could synergistically act to improve quail productivity.

Fayoum J. Agric. Res. \& Dev., Vol. 21, No. 2, July, 2007 
PRACTICAL ASPECTS OF ENZYME-PROBIOTICS...............

MATERIALS AND METHODS

Experimental Procedure:

Four hundred and eighty one-day-old Japanese quail (Coturnix Coturnix Japonica) were obtained at day of hatch from a commercial hatchery, wing banded, individually weighed and were assigned randomly to four equal experimental groups of 120 birds each. Birds of each treatment were further subdivided into three replicates of 40 birds each. The birds were brooded in thermostatically controlled batteries. The lighting pattern was $23 \mathrm{~h}$ light: $1 \mathrm{~h}$ dark. Feed and water were added ad libitum.All birds were kept under the same managerial hygienic and environmental conditions throughout the entire experimental period that lasted for 6 weeks during the summer time.

Diets:

A conventional corn - soybean meal based diet was formulated to meet the minimum National Research Council recommendations (NRC, 1994). The basal diet was supplemented with three experimental feed additives. The first feed additive was Xylam; it was used as a source of enzyme supplement (A product of Bacilius subtilis; each gram contains endo-1.4 $\beta$-xylanase 1260U, $\alpha$ amylase $8000 \mathrm{U}$ and wheat flour as a carrier. Xylam was added at the level of $0.5 \mathrm{~g} / \mathrm{kg}$ diet. The second feed additive was Samu Biogen; it was used as a source of enzymes and probiotics; each kg contains Bacillus subtitles Matta not less than $1 \times 10^{11}$ unit, cellulase 20000 unit, protease 250000 unit, $\alpha$ amylase 400000 unit, $\beta$-amylase 20000 unit, and corn starch as a carrier. Samu Biogen was added at the level of $0.2 \mathrm{~g} . / \mathrm{kg}$ diet.The third feed additive was Organic Green Culture; it was used as a source of enzymes and probiotics, each $\mathrm{kg}$ contains Saccharomyces cerevisae $1 \times 10^{\mathrm{I1}} \mathrm{IU}$, Lactobacillus acidophilus $1 \times 10^{11}$, Bacillus subtilis $1 \times 10$, Apergillus oryzae $1 \times 10^{11}$, protease $250000 \mathrm{IU}$, amylase $25000 \mathrm{IU}$, lipase 15000 , cellulase 15000 , and phytase 15000 . It was added at the level of $1.5 \mathrm{~g} / \mathrm{kg}$ diet. All feed additives were recommended by the producers. The composition and chemical analysis of the basal experimental diet is illustrated in Table 1.

Growth performance traits:

Individual body weight, weight gain and feed consumption were recorded weekly. Feed conversion was calculated on a replicates basis. The general status of birds was noticed and dead birds were removed, weighed and kept for post mortem examination.

Lymphoid and other organs weight:

At the end of the experiment, three birds of each replicate around the average weight were chosen, weighed and slaughtered after fasting for 10 hours. After slaughtering and complete bleeding, the internal organs (intestine, gizzard, liver, heart, bursa, thymus, and spleen) were removed carefully and weighed.

\section{Hematological traits:}

At the end of the experiment, five birds from each replicate were slaughtered after fasting for 10 hours. Two $\mathrm{ml}$ of blood were obtained from each bird in a sterile centrifuge tube containing heparin (20 IU/ ml) for counting the blood cells. In addition, three $\mathrm{ml}$ of blood were also taken from each bird in sterile tubes to get serum for assessing Hemagglutination Inhibition titer test (HI). The count of red blood cells (RBC's), white blood cells (WBC's) and differential white blood cells were determined according to the procedures outlined by Schalm et al. (1975).

Fayoum J. Agric. Res. \& Dev., Vol. 21, No. 2, July, 2007 
Table 1. Composition and calculated analysis of the basal diet

\begin{tabular}{|c|c|}
\hline Ingredients & $(\%)$ \\
\hline Yellow corn & 55.70 \\
\hline Soybean meal (44\%) & 33.13 \\
\hline Corn gluten meal & 7.85 \\
\hline Limestone & 0.85 \\
\hline Di-Calcium phosphate & 1.59 \\
\hline Dl-Methionine & 0.08 \\
\hline L-lysine & 0.18 \\
\hline Salt $(\mathrm{NaCl})$ & 0.32 \\
\hline Vitamins and minerals premix ${ }^{*}$ & 0.30 \\
\hline Total & 100 \\
\hline$\frac{\text { Calculated analysis }}{\text { Crude protein }(\%)}^{* *}$ & 24.23 \\
\hline Metabolizable Energy (kcal/kg) & 2900 \\
\hline $\mathrm{Ca}, \%$ & 0.80 \\
\hline Available P, \% & 0.45 \\
\hline Ether extract, \% & 2.58 \\
\hline Crude fiber, \% & 3.65 \\
\hline Lysine, \% & 1.30 \\
\hline Methionine, \% & 0.50 \\
\hline
\end{tabular}

* Vitamin and minerals premix provide per kilogram of diet the following: V.A 10000 IU; V.D3 2000 ICU; V.E 15 IU; V.K3 3mg; riboflavin $10 \mathrm{mg}$; Ca pantothenate, 10 $\mathrm{mg}$; niacin, $20 \mathrm{mg}$; choline chloride, $500 \mathrm{mg}$; V.B12 $10 \mu \mathrm{g}$; V.B6 $1.5 \mathrm{mg}$; thiamine, $2.2 \mathrm{mg}$; folic acid, 1mg, biotin , $50 \mu \mathrm{g}$; Mn $55 \mathrm{mg}$; Zn 50mg; Fe 30; Cu, 10mg; $\mathrm{Se}, 1 \mathrm{mg}$.

** NRC, (1994)

\section{Plasma biochemical analysis:}

Plasma was obtained immediately by centrifugation of heparinized blood for $10 \mathrm{~min}$. at $3000 \mathrm{rpm}$ and frozen rapidly in ependorf tubes until the time of analysis. Plasma globulin was calculated as the difference between plasma total protein and albumin. The activities of aspartate aminotransferase (AST) and alanine aminotransferase (ALT) were also measured. All plasma samples were analyzed by using specific diagnostic kits (Bio Merieux, France) as recommended by Armstrong and Carr (1964) and Bogin and Keller (1987).

\section{Immuno response test:}

The birds were vaccinated at 7 day of age by Lentogenic NDV Hitchner $\beta$ vaccine in lyopholyzed form with minimum titer of $10^{9}$ EID $_{50}$ (Izo Vac, 1000, Izo Laboratories, Italy). The lentogenic lasota vaccinal strain of NDV that passed two times in the allantoic sac of 9-11 days old chick embryo was used to vaccinate the birds at 17 and 27 days of age. The birds were vaccinated by eye drop using a standard dropper $(0.5 \mathrm{ml} /$ drop $)$; each bird received 2 drops, one in each eye. At 21, 35, and 42 days of the experiment, three $\mathrm{ml}$ of blood were taken from each bird in a sterile centrifuge tube. After centrifugation, serum was used immediately for assessing HI titer. The test was performed according to the standard procedure described by Majiyabe and Hitchner (1977).

Fayoum J. Agric. Res. \& Dev., Vol. 21, No. 2, July, 2007 
PRACTICAL ASPECTS OF ENZYME-PROBIOTICS.................

Bacterial Counts:

Total bacterial count:

The test was performed according to the standard procedure described

by Tellez et al., (1993). One gram of the cecal contents was diluted in $99 \mathrm{ml}$ of nutrient broth or sterile physiological saline in $250 \mathrm{ml}$ Erylen Myer flasks. Then $1 \mathrm{ml}$ of this mixture is re-suspended in $9 \mathrm{ml}$ of the same dilution system in $15 \mathrm{ml}$ sterile glass test tubes. Then carry on the 10 fold serial dilution. From each test tube, transfer $1 \mathrm{ml}$ from each dilution and spread on one nutrient agar medium plate, trypticase soy agar or brain heart infusion agar plates. Plates are incubated for $24 \mathrm{hrs}$ at $37 \mathrm{C}$. Then colonies are counted by a hand glass magnifier. The total bacterial count is obtained by multiplying the number of the colonies in the last dilution plate (lowest) by the inverse log. 10 of this plate. Thus we can obtain the total bacterial count. Total bacterial count did not include beneficial lactobacillus spp.

\section{Total E.coli count:}

One gram of the cecal contents was diluted in $99 \mathrm{ml}$ of nutrient broth or sterile physiological saline in $250 \mathrm{ml}$ Erylen Myer flasks. Then $1 \mathrm{ml}$ of this mixture is re-suspended in $9 \mathrm{ml}$ of the same dilution system in $15 \mathrm{ml}$ sterile glass test tubes. Then carry on the 10 fold serial dilution. From each test tube, transfer $1 \mathrm{ml}$ from each dilution and spread on one MacConkey agar plate, one brilliant green agar plate or one SS agar plate. Plates are incubated for $24 \mathrm{hrs}$ at $37 \mathrm{C}$. Then colonies are counted by a hand glass magnifier. The total bacterial count is obtained by multiplying the number of the colonies in the last dilution plate (lowest) by the inverse log. 10 of this plate. Thus we can obtain the total bacterial count.

Statistical analysis:

All data were subjected to statistical analysis by one way analysis of variance according to SAS program (SAS, Institute, Inc., 1996). Significant differences among means were tested by the methods of Duncan (1955).

\section{RESULTS \\ Performance traits:}

The effects of Xylam, Sam Biogen and Organic Green Culture supplementation on Japanese quail's performance are illustrated in Table 2. Initial body weight did not statistically differ among experimental groups. Statistical differences were noticed in final body weight between control and the experimental treated groups. At the end of the experiment, Organic Green Culture supplementation increased significantly final body weight by $13.4 \%$ compared with the control. Meanwhile, final body weight of quail receiving Samu Biogen or Xylam increased significantly $(\mathrm{P} \leq 0.01)$ by 8.5 and $7.1 \%$, respectively compared with the control. Body weight gain was also influenced significantly by all experimental diets. Organic Green Culture supplemented diet increased weight gain by $14.3 \%$ compared with the control while weight gains of birds received diets supplemented with Samu Biogen or Xylam were statistically equal; their values were increased by 9.3 , and $7.8 \%$, respectively compared with the control.

Feed consumption was affected significantly by Organic Green Culture, Samu Biogen, and Xylam compared with the control. Supplementing Organic Green Culture to diet significantly decreased $(\mathrm{P} \leq 0.05)$ feed consumption by $13.4 \%$ followed by quails receiving Samu Biogen (3.8\%). Meanwhile, quails receiving Xylam in their diet significantly consumed more feed $(2.0 \%)$ than those fed the control diet.

Fayoum J. Agric. Res. \& Dev., Vol. 21, No. 2, July, 2007 
Feed conversion ratio was significantly improved where quails receiving diet supplemented with Organic Green Culture exhibited the best feed conversion ratio followed by quail fed diet supplemented with Samubiogen, and Zylam compared with the control.

Mortality rate decreased with Organic Green Culture, Samu Biogen and Xylam supplemented diets. The birds received Organic Green Culture showed the lower mortality rate compared to the other groups. Samu Biogen and Xylam supplemented diets were numerically equal but less than those fed the control diets. The mortality $\%$ of quails fed diet supplemented with Organic Green Culture suggests a tendency to reduce mortality rate in quails fed this supplement.

Table (2): Performance traits of growing Japanese quails as affected by different experimental treatments.

\begin{tabular}{|l|c|c|c|c|c|}
\hline Traits & Control & Xylam & $\begin{array}{c}\text { Samu } \\
\text { Biogen }\end{array}$ & $\begin{array}{c}\text { Organic } \\
\text { Green } \\
\text { Culture }\end{array}$ & Significance \\
\hline Initial Wt. (g) & $8.3 \pm 0.35$ & $8.2 \pm 0.34$ & $7.8 \pm 0.30$ & $8.1 \pm 0.30$ & NS \\
\hline Final Wt. (g) & $169.0 \pm 6.4^{\mathrm{c}}$ & $181.0 \pm .9^{\mathrm{b}}$ & $183.3 \pm 3.4^{\mathrm{b}}$ & $191.7 \pm 3.8^{\mathrm{a}}$ & $* *$ \\
\hline Gain (g) & $160.7 \pm 6.4^{\mathrm{c}}$ & $173.3 \pm 4.8^{\mathrm{b}}$ & $175.6 \pm 3.3^{\mathrm{b}}$ & $183.6 \pm 4.0^{\mathrm{a}}$ & $*$ \\
\hline Feed intake (g) & $801.8 \pm 3.5^{\mathrm{b}}$ & $817.7 \pm 3.7^{\mathrm{a}}$ & $771.4 \pm 2.4^{\mathrm{c}}$ & $694.2 \pm 2.3^{\mathrm{d}}$ & $*$ \\
\hline Feed:gain ratio & $4.99 \pm 0.2^{\mathrm{d}}$ & $4.73 \pm 0.21^{\mathrm{c}}$ & $4.39 \pm 0.12^{\mathrm{b}}$ & $3.78 \pm 0.11^{\mathrm{a}}$ & $*$ \\
\hline Mortality rate \% & $13.3^{\mathrm{c}}$ & $8.3^{\mathrm{b}}$ & $8.3^{\mathrm{b}}$ & $6.7^{\mathrm{a}}$ & $* *$ \\
\hline
\end{tabular}

Means within row for each item having different superscript differ significantly

NS = Not significant $\quad * \mathrm{P} \leq 0.05 \quad * * \mathrm{P} \leq 0.01$

\section{Internal organs weights:}

Lymphoid organs weight and other organs indices data as affected by Organic Green Culture, Samu Biogen, and Xylam supplementation are demonstrated in Table 3.

Organic Green Culture supplemented group had significantly higher weight of heart, thymus, spleen, and bursa compared with the control. Samu Biogen and Xylam supplemented groups had statistically equal effect on bursa, spleen, and heart. Thymus percentage showed another trend where Organic Green Culture and Samu Biogen were statistically equal. Organic Green Culture supplemented group induced lower intestine weight followed by birds fed Samu Biogen and Xylam compared with the control while the gizzard weight was not affected. The high liver weight values noticed in birds fed Organic Green Culture followed by Samu Biogen and Xylam.

\section{Hematological Assessment:}

The effects of Organic Green Culture, Samu Biogen, and Xylam on some hematological parameters are tabulated in Table 4.

Organic Green Culture, Samu Biogen, and Xylam supplementation had a significant $(\mathrm{P} \leq 0.05)$ and dynamic impact on the hematological profile of quail. The RBC's count was significantly increased in response to Organic Green Culture; its value was $131.5 \%$ of the control. The RBC's count in birds fed diet supplemented with Samu Biogen was significantly increased to $119.6 \%$ of the control, while in case of Xylam supplemented diet, it was increased to $117.4 \%$ of the control. 
PRACTICAL ASPECTS OF ENZYME-PROBIOTICS.

Table (3): Lymphoid and other organs weight of growing Japanese quails as affected by different experimental treatments.

\begin{tabular}{|l|c|c|c|c|c|}
\hline \multicolumn{1}{|r|}{ Treatments } & Control & Xylam & $\begin{array}{c}\text { Samu } \\
\text { Biogen }\end{array}$ & $\begin{array}{c}\text { Organic } \\
\text { Green } \\
\text { Culture }\end{array}$ & Significance \\
\hline Liver $(\mathbf{g})$ & $2.00 \pm 0.19^{\mathrm{b}}$ & $2.20 \pm 0.06^{\mathrm{b}}$ & $2.40 \pm 0.29^{\mathrm{b}}$ & $2.65 \pm 0.15^{\mathrm{a}}$ & $*$ \\
\hline Heart $(\mathbf{g})$ & $0.66 \pm 0.04^{\mathrm{b}}$ & $0.75 \pm 0.37^{\mathrm{b}}$ & $0.80 \pm 0.07^{\mathrm{b}}$ & $1.07 \pm 0.10^{\mathrm{a}}$ & $* *$ \\
\hline Thymus & $0.18 \pm 0.03^{\mathrm{c}}$ & $0.22 \pm 0.03^{\mathrm{b}}$ & $0.25 \pm 0.03^{\mathrm{a}}$ & $0.27 \pm 0.03^{\mathrm{a}}$ & $*$ \\
\hline Spleen $(\mathbf{g})$ & $0.05 \pm 0.01^{\mathrm{c}}$ & $0.09 \pm 0.01^{\mathrm{b}}$ & $0.11 \pm 0.01^{\mathrm{b}}$ & $0.15 \pm 0.01^{\mathrm{a}}$ & $*$ \\
\hline Bursa $(\mathbf{g})$ & $0.05 \pm 0.01^{\mathrm{c}}$ & $0.09 \pm 0.06^{\mathrm{b}}$ & $0.11 \pm 0.01^{\mathrm{b}}$ & $0.4 \pm 0.01^{\mathrm{a}}$ & $*$ \\
\hline Gizzard $(\mathbf{g})$ & $2.40 \pm 0.24$ & $2.45 \pm 0.14$ & $2.60 \pm 0.25$ & $2.70 \pm 0.15$ & $\mathrm{NS}$ \\
\hline Intestine, $\mathbf{( g )}$ & $4.70 \pm 0.20^{\mathrm{a}}$ & $4.40 \pm 0.13^{\mathrm{b}}$ & $4.20 \pm 0.13^{\mathrm{b}}$ & $4.10 \pm 0.26^{\mathrm{b}}$ & $*$ \\
\hline
\end{tabular}

Means within row for each item having different superscript differ significantly

$\mathrm{NS}=$ Not significant $\quad * \mathrm{P} \leq 0.05 \quad * * \mathrm{P} \leq 0.01$

The same trend was quite evident for WBC's count; it was increased in birds fed Organic Green Culture supplemented diet to 1.2 fold of the control. The corresponding value for birds received diet supplemented with Xylam was 1.03 fold. Heterophils $(\mathrm{H})$, Basophiles(B) and lymphocytes (L)percentage were higher with Organic Green Culture by 9.8, 38.7, 6.6\%, respectively, compared to the control. The same trend was noticed with Samu Biogen where heterophils, basophiles and lymphocytes increased by $9.4,33.3,3.7 \%$, respectively, compared to the control while Xylam supplemented group showed a little variation compared to the control.

Table (4): Hematological traits of growing Japanese quails as affected by different experimental treatments.

\begin{tabular}{|c|c|c|c|c|c|}
\hline Traits Treatments & Control & Xylam & $\begin{array}{c}\text { Samu } \\
\text { Biogen }\end{array}$ & $\begin{array}{c}\text { Organic } \\
\text { Green } \\
\text { Culture }\end{array}$ & Significance \\
\hline RBC's $\left(\mathrm{X10}^{3} / \mathrm{ml}\right)$ & $2.70 \pm 0.15^{\mathrm{d}}$ & $3.17 \pm 0.14^{\mathrm{c}}$ & $3.23 \pm 0.21^{\mathrm{b}}$ & $3.55 \pm 0.19^{\mathrm{a}}$ & * \\
\hline WBC's $\left(X 10^{3} / \mathrm{ml}\right)$ & $22.56 \pm 0.93^{\mathrm{d}}$ & $23.20 \pm 0.53^{\mathrm{c}}$ & $25.20 \pm 0.39^{\mathrm{b}}$ & $27.08 \pm 0.37^{\mathrm{a}}$ & * \\
\hline Heterophils(H), (\%) & $40.16 \pm 0.54^{\mathrm{d}}$ & $40.83 \pm 0.60^{\mathrm{c}}$ & $43.93 \pm 0.60^{\mathrm{b}}$ & $44.08 \pm 0.37^{\mathrm{a}}$ & * \\
\hline Basophiles(B) (\%) & $3.00 \pm 0.55^{\mathrm{b}}$ & $3.16 \pm 0.36^{b}$ & $4.00 \pm 0.30^{\mathrm{a}}$ & $4.16 \pm 0.60^{\mathrm{a}}$ & * \\
\hline lymphocytes (L) (\%) & $40.66 \pm 1.05^{\mathrm{d}}$ & $41.00 \pm 0.77^{\mathrm{c}}$ & $42.17 \pm 0.76^{\mathrm{b}}$ & $43.33 \pm 1.64^{\mathrm{a}}$ & *** \\
\hline
\end{tabular}

Means within row for each item having different superscript differ significantly

$* \mathrm{P} \leq 0.05$

$* * \mathrm{P} \leq 0.01$

\section{Plasma constituents:}

Table 5 summaries the effect of Organic Green Culture, Samu Biogen, and Xylam supplementation on plasma total protein, albumin, globulin, AST and ALT. It is obvious that there was an interspecific variation in all investigated serum biochemical variables between treated groups and control except AST and ALT.

Plasma total protein increased significantly in birds received Organic Green Culture and Samu Biogen by $41.5 \%$ and $22.0 \%$, respectively, compared to the control. At the same time, no significant difference in total protein was detected between Xylam supplemented group and control group. The highest value of plasma albumin was observed in birds received Organic Green Culture followed by Samu Biogen and xylam compared with the control. A similar pattern of response to that described for total protein was noticed for globulin.Glubulin concentration increased with Organic Green Culture by

Fayoum J. Agric. Res. \& Dev., Vol. 21, No. 2, July, 2007 
$48.7 \%$ followed by $26.1 \%$ with Samu Biogen compared to the control.Glubulin in birds received Xylam was statistically differ compared with the control. Plasma AST and ALT were not markedly affected by Xylam, Samu Biogen and Organic Green Culture compared with the control.

Table (5): Plasma constituents of growing Japanese quails as affected by different experimental treatments.

\begin{tabular}{|l|c|c|c|c|c|}
\hline \multicolumn{1}{|c|}{ Treatments } & Control & Xylam & $\begin{array}{c}\text { Samu } \\
\text { Biogen }\end{array}$ & $\begin{array}{c}\text { Organic } \\
\text { Green } \\
\text { Culture }\end{array}$ & Significance \\
\hline Traits & $2.46 \pm 0.06^{\mathrm{c}}$ & $2.53 \pm 0.12^{\mathrm{b}}$ & $3.00 \pm 0.02 \mathrm{~g}^{\mathrm{a}}$ & $3.40 \pm 0.20 \mathrm{~g}^{\mathrm{a}}$ & $* *$ \\
\hline Albumin $(\mathbf{g} / \mathbf{d} \mathbf{l})$ & $1.31 \pm 0.06^{\mathrm{c}}$ & $1.22 \pm 0.06^{\mathrm{b}}$ & $1.55 \pm 0.04^{\mathrm{b}}$ & $1.77 \pm 0.20^{\mathrm{a}}$ & $*$ \\
\hline Glubulin $(\mathbf{g} / \mathbf{d l})$ & $1.15 \pm 0.06^{\mathrm{c}}$ & $1.31 \pm 0.02^{\mathrm{b}}$ & $1.45 \pm 0.04^{\mathrm{b}}$ & $1.71 \pm 0.06^{\mathrm{a}}$ & $* *$ \\
\hline AST (u/L) & $42.56 \pm 2.9$ & $38 \pm 2.6$ & $37.63 \pm 3.1$ & $37.40 \pm 3.5$ & NS \\
\hline ALT (U/L) & $1.30 \pm 0.22$ & $1.33 \pm 0.21$ & $1.16 \pm 0.16$ & $1.16 \pm 0.16$ & NS \\
\hline
\end{tabular}

Means within row for each item having different superscript differ significantly

NS $=$ Not significant $\quad * \mathrm{P} \leq 0.05 \quad * * \mathrm{P} \leq 0.01$

Table 6 showed the results of HI titer at 21,35, and 42 days of age. The results indicated that HI titer was significantly higher in the birds received Organic Green Culture followed by those fed Samu Biogen then those received Xylam as compared with the control group. The HI titer has reached its maximum value at the end of the experiment (42 days) with Organic Green Culture compared with the control.

Bacterial counts as affected by different tretments are demonstrated in Table 7. The lowest bacterial count was observed with Organic Green Culture it decreased by $91.8 \%$ followed by Samu Biogen $(81.8 \%)$ then Xylam supplemented group (76.4\%) compared with the control. The same pattern was noticed with E.Coli count. The Organic Green Culture supplemented group decreased E.Coli count than the other treated group, it decreased by $93.3 \%$ compared with the control while E.Coli count decreased by $80.0 \%$, 76.7\%, with Samu Biogen and xylem, respectively compared with the control. These results may suggest the antibacterial effect of Organic Green Culture in the intestine.

Table (6): Hemagglutination inhibition test (H1/ $\log _{2}$ titers) in growing Japanese quails as affected by different treatments.

\begin{tabular}{|l|c|c|c|c|c|}
\hline Traits Treatments & Control & Xylam & $\begin{array}{c}\text { Samu } \\
\text { Biogen }\end{array}$ & $\begin{array}{c}\text { Organic } \\
\text { Green } \\
\text { Culture }\end{array}$ & Significance \\
\hline At 21 day & $3.8 \pm 0.50^{\mathrm{c}}$ & $3.8 \pm 0.40^{\mathrm{c}}$ & $4.1 \pm 0.40^{\mathrm{b}}$ & $5.8 \pm 0.40^{\mathrm{a}}$ & $* *$ \\
\hline At 35 day & $3.1 \pm 0.30^{\mathrm{c}}$ & $4.5 \pm 0.30^{\mathrm{b}}$ & $4.5 \pm 0.30^{\mathrm{b}}$ & $5.5 \pm 0.30^{\mathrm{a}}$ & $* *$ \\
\hline At 42 day & $3.3 \pm 0.34^{\mathrm{d}}$ & $3.8 \pm 0.34^{\mathrm{c}}$ & $4.8 \pm 0.54^{\mathrm{b}}$ & $5.0 \pm 0.34^{\mathrm{a}}$ & $* *$ \\
\hline
\end{tabular}

Means within row for each item having different superscript differ significantly

$* \mathrm{P} \leq 0.05 \quad * * \mathrm{P} \leq 0.01$

Fayoum J. Agric. Res. \& Dev., Vol. 21, No. 2, July, 2007 
PRACTICAL ASPECTS OF ENZYME-PROBIOTICS.

Table (7): Bacterial counts (log ${ }_{10} /$ gram of cecal samples) in growing Japanese quails as affected by treatments.

\begin{tabular}{|l|c|c|c|c|c|}
\hline Traits & Control & $\begin{array}{c}\text { Organic } \\
\text { Green } \\
\text { Culture }\end{array}$ & $\begin{array}{c}\text { Samu } \\
\text { Biogen }\end{array}$ & Xylam & Significance \\
\hline Total bacterial count & $11 \times 10^{4 \mathrm{~d}}$ & $9 \times 10^{3 \mathrm{a}}$ & $20 \times 10^{3 \mathrm{~b}}$ & $26 \times 10^{3 \mathrm{c}}$ & $* *$ \\
\hline Total $E$. coli count & $3 \times 10^{4 \mathrm{~d}}$ & $2 \times 10^{3 \mathrm{a}}$ & $6 \times 10^{3 \mathrm{~b}}$ & $7 \times 10^{3 \mathrm{c}}$ & $* *$ \\
\hline & & & & & \\
\hline
\end{tabular}

Means within row for each item having different superscript differ significantly

$* \mathrm{P} \leq 0.05 \quad * * \mathrm{P} \leq 0.01$

\section{DISCUSSION}

The experimental treatments used in the current study aimed to improve the nutritional value of corn-soybean based diets. It is well known that poultry do not secrete all kinds of enzymes needed for a complete digestion of the components of feedstuffs. Thus, supplementing poultry diets with enzymes is becoming urgent. The feed enzyme industry focuses primarily on removing the antinutritive effects of non-starch polysaccharides (NSP) from diets (Annison, 1991). However, microbial enzymes targeting these polymers have, for this reason, shown highly positive results in both enhancement of performance and reduction of excreta volume and moisture (Lazaro et al., 2004).

The current results showed that Organic Green Culture, Samu Biogen and Xylam supplemented to the corn-soybean based diet improved body weight and weight gain compared to the un-supplemented diet. Xylam supplementation improved feed conversion by decreasing feed consumption. Enzymes addition improved feed utilization of feeds as indicated by ElHusseiny et al. (1995). Friesen et al. (1991) showed that enzyme supplementation improved feed conversion efficiencies due to the direct effect of enzyme on cereal grain nutritive value. It is demonstrated that enzymes supplementation accelerate the passage of the digesta (Almirall and Esteve-Garica, 1994), and therefore, induce a higher feed intake, the decrease in viscosity was parallel to an improvement in feed conversion ratio, energy and starch digestibility (Choct $\boldsymbol{e t}$ al., 1995). The increase in the energy and nutrient supply might be an essential factor for the intensified growth of birds fed enzyme supplemented diets. Wu et al., (2004) pointed out that the positive effects of enzymes supplementation could be attributed to improve nutrients digestibility in young chicks as well as improve the digestion of soluble and insoluble NSP in corn and soybean meal (SBM). Xylanase supplementation tended to increase goblet cell numbers in the duodenum and decrease crypt depth in the jejunum and ileum, this indicate that cell wall degrading enzymes had stimulating effect on absorptive capacity. Hashish and El-Ghamry (1998) reported that the effectiveness of enzyme preparation may be due to the improvement in apparent protein digestibility by increasing the activities of proteolytic enzymes in small intestine. Veldman and Vahi (1994) showed that viscosity caused by xylans has a detrimental effect on dry matter and mineral absorption in broiler. Xylanases enzymes have been shown to improve the performance of broiler (Flores et al., 1994 and Choct et al., 1995), throughout the degrading of viscous non starch polysaccharides starch and pentosan digestibility (Annison, 1992), it has been suggested that the improvements caused by the xylanase preparation were due

Fayoum J. Agric. Res. \& Dev., Vol. 21, No. 2, July, 2007 
to a reduction in pentosan concentration in the digestive tract. A partial hydrolysis of the xylan by xylanase supplemented diet results in a large decrease in digesta viscosity which would create an environment more conductive to optimum digestion of crude protein and carbohydrates. Within nutrients needs, ME intake is well documented to influence body composition (Morris, 2004) and performance of growing broiler (Leeson et al., 1996).Palander et al., (2005) reported that the use of enzymes containing $\beta$ glucanase-xylanase improved AMEn in wheat, barley and oat based diets for turkeys. The results observed by Adeola and Bedford, (2004) showed that xylanase alone improved TME more in high-viscosity than low-viscosity wheat when fed to the ducks.

Malathi and Devegowda (2001) reported that the level of NSP is up to $29 \%$ in SBM and $9 \%$ in corn. Both maize and soybean provide targets for NSP enzymes alone or in conjunction with other enzyme classes potentially able to improve nutrient availability. However, Hong et al., (2002) found that enzyme cocktail improved the digestibility of a corn-soybean based diet for ducks. Soybean cells walls contain a very high proportion of pectic polysaccharides (galacturonans and associated arabinogalactans) which account for approximately half of the NSP present. Enzyme targets in soybean are the water-soluble carbohydrates (WSC) which account for $10 \%$ by weight of the bean and the pectic polysaccharides that account for a further $10 \%$.Huisman et al. (2000) pointed out that disruption of the pectic fraction has a number of potential benefits. These include avoiding any contribution to digesta viscosity of the pectic polysaccharides and ensuring full disruption of the cellular matrix of the meal. Either or both of these effects can significantly improve nitrogen retention. Scholtyssek and Knorr, (1987) have reported some improvement in $\mathrm{N}$ retention when diets were supplemented with cellulolytic enzymes preparations. The addition of enzyme complex could have released cell wall encapsulated proteins, which were subsequently utilized. Marsman et al. (1997) showed that disruption of the cell-wall matrix by the exogenous glycanacses in the upper intestine leads to easy access of the endogenous proteolytic enzyme to digest the entrapped proteins.

Maize, like other cereal grains, has a cellular endosperm with thin endosperm cell walls and a cell wall composition similar to that of wheat. Highly branched arabinoxylans predominate in the endosperm, but mix linked glucan and a small amount of cellulose are also present. The cell wall forming the outer layers of kernel, (the pericarp and seed coat) are similarly rich in xylans and in cellulose but, unlike other cereals, are not extensively lignified (Saulnier et al., 1995). However, detailed structural analysis of soybean and to lesser extent maize polysaccharides suggests that enzymes known in commercial preparations may be appropriate and effective. Better results could be achieved if formulation included activities effective against the novel structures that have now been identified.

The observed positive effect of enzymes on chick growth could be also attributed to improve gut environment, reduced pathogenic bacteria, i.e. enterobacteria, total anaerobe microbes, and gram-positive cocci and entero cocci and reduced digesta viscosity even if non-viscous grains e.g. maize and sorgum (Cowan, 1995). In this regard, Bedford and Apajalahti (2002) observed that a considerable amount of starch remained encapsulated in the cell walls in the small intestine of chickens; this encapsulation effect seems to be more apparent in non-viscous cereal grains than viscous cereals.

Fayoum J. Agric. Res. \& Dev., Vol. 21, No. 2, July, 2007 
Brown (1996) reported that corn starch is not completely digested at the terminal ileum, and their digestion is only in the hindgut. He suggested that some corn starch is somewhat resistant. The enzyme cocktail is expected to act on resistant starch and improve accessibility and solubility of nutrients, thus improving ME and protein digestibility. Mahagna et al. (1995) reported a decrease in pancreatic chemotrypsin activity in chicks supplemented with only amylase or protease. Thus exogenous enzymes used in the diets of young chicks would be very beneficial in improving nutrients digestibility either by supplying enzymes that the chicks cannot produce in sufficient quantity by itself or by reducing the requirement for the enzymes, thus making more nutrient and energy available for growth of the chicks at that critical stage (Olukosi et al., 2007).

Zyla et al. (1996) showed that complete dephosphorylation of cornSBM diet needs to use an enzyme cocktail rather than one enzyme; the cocktail was more effective than phytase alone at promoting the performance of turkey poults. Onyango et al. (2005) reported some improvement in $\mathrm{N}$ retention and some amino acids over the low- $\mathrm{P}$ diet in broiler chicks receiving corn- soybean based diet supplemented with phytase. The total fecal and ileal digestibility observed by Olukosi et al., (2007) showed that both enzyme cocktail and phytase improved P liberation.

Phytate molecule is not the only molecule that is responsible for nutrient's chelating, there is evidence that some soluble fibers, including soluble NSP, are responsible as well (Frolich, 1990). It has been shown that soluble NSP and phytic acid are in the aleurone cell layer. Parkkonen et al. (1997) reported that xylanase increased the permeability of the aleurone cell wall layer, which is the site of phytate storage. It is possible that enzyme cocktail, by improving aleurone layer permeability, enhances the access of endogenous phytase to phytate molecules, hence improving $\mathrm{P}$ digestibility and retention.

With increasing concern about antibiotics resistance, there is an increasing interest in finding alternatives to antibiotics in poultry production. Probiotics are one of the approaches that have a potential to reduce chances of infection in poultry and subsequent contamination of poultry product. The Organic Green Culture and Samu Biogen used in the present work are considered as a commercial feed additive containing probiotics and enzymes in poultry feed. The Organic Green Culture and Samu Biogen induced beneficial effect on broiler performance. The current results are compatible with those reported by Ahmad (2006) who pointed out that growth pattern of treated birds showed an increase in weight gain relative to the control. The current data showed also that supplemented chicks consumed less feed than the control. In spite of less feed consumed, treated quails showed a better feed conversion ratio. These results are in harmony with those reported by Silva $e t$ al., (2000) who mentioned that supplementation with L. acidophilus did produce a significant improvement in feed conversion, a feature that could, perhaps, be beneficial with respect to the economic prospects for treatments.

The improvement in live body weight is mainly due to maintaining the beneficial bacteria such as lactobacillus in the intestinal tract of the birds. Lactobacillus in their natural environment competes with the undesirable organisms for space and nutrients as reported by Jin et al., (1996).Lactobacilli are among the indigenous flora colonizing the chick crop. Colonizing bacteria adhere firmly to the mucosal epithelium (Beachey, 1980). Useful bacterial growth facilitates the fermentation process in all kind of animals. This

Fayoum J. Agric. Res. \& Dev., Vol. 21, No. 2, July, 2007 
fermentation is of nutritional significant in most animals. The oligo-and polysaccharides have been reported to be responsible for significant changes in the number and metabolism of microflora colonizing the gut because they are not digested in the small intestine and provide substrates for fermentative bacteria (Cummings, 1981) .In the chicken crop small amount of starch is broken down by the fermentative process. The bacterial breakdown produces various types of vitamins (Fuller, 1997) and organic acids, which provide energy to the host as well as stimulate the growth (Lan et al., 2003). Ahmad (2004) reported that probiotics have an effect on the main physiological functions of the gastrointestinal tract with an increase of crypt cells proliferation of small intestines leads to more digestion, absorption and propulsion as well as competition for adhesion receptors in the intestine, competition for nutrients, reduction of toxin release and immuostimulatin (Nahashon et al., 1994).

In the current investigation the birds received diet supplemented with Xylam decreased the intestine weight compared with control. These results are compatible with those observed by Brenes et al. (1993) who stated that the addition of enzyme reduced small intestine and colon size. The increase in gastrointestinal tract size may, therefore, be an adaptive response to an increase in their need for enzymes. The reduction in the relative organs weight of birds received enzymes is also of direct economic. In the current study, lymphoid organs followed the opposite trend compared to relative organs weight where Organic Green Culture and Samu Biogen induced significant increase in lymphoid organs weights. This increase may be connected to the effect of Organic Green Culture and Samu Biogen on lymphoid organs activity. Measures of immunity that have been commonly used and assessed in poultry are lymphoid organ weights (Pope, 1991) and antibody response to foreign antigens (Klasing, 1998).Lymphoid organs weights are easily measured and reflect the body's ability to provide lymphoid cells during an immune response (Heckert et al., 2002).

In the current study the hematological assessment showed that the treatments may stimulate cellular and humoral immunity as indicated by WBC's counts, HI titer test and globulin concentration. It is well known that cellular immunity is a product of (T) lymphocytes which it forms in the thymus gland (immune cells have the ability of removing the foreign antigenic invader through phagocytosis and macrophages production) as well as spleen; it serves as the site for interaction between foreign antigens and different types of leukocytes (Klasing, 1998).Humoral immunity; is a product of (B) lymphocytes; it is formed in the bursa of fabricius and plays an important role in producing antibodies (circulating antibody, Ab's) that can inactivate the invading agent by agglutination, precipitation, neutralization, and lyses.

The WBC's counts were increased in Organic Green Culture and Samu Biogen treated groups compared to the Xylam treated group and control. This result may indicate that Organic Green Culture and Samu Biogen stimulate the bursa, thymus, and spleen to produce more lymphocytes through the improvement in gut ecology and decreased pathogenic bacteria. This helps the birds to be healthier and leads in turn to increase body weight and lymphoid organs weights and activity as stated by Ali (1999).

It is interesting to know that some viruses have the ability to agglutinate to the RBC's.This character is called Hemagglutination (HI).The principle for HI test depends on the utilization of serum vaccinated birds to

Fayoum J. Agric. Res. \& Dev., Vol. 21, No. 2, July, 2007 
prevent the natural hemagglutination of some viruses as NDV to attach to erythrocytes. It indicated that the higher concentration of antibodies in blood means higher HI titers.

The HI titer test data in the current investigation which is considered as indicator for humoral immunity confirmed that both Organic Green Culture and Samu Biogen increased the antibody production. Havenaar and Spanhaak (1994) reported that probiotics stimulate the immunity where flora from probiotics migrate throughout the gut wall and multiply to a limited extent or that antigen may be released by the dead organisms are absorbed and thus stimulate the immune system. Ahmad (2006) reported that the improvement in the immune system could be attributed to increase macrophage activity, phagocytoses and the production of antibodies as well as increased the local antibodies at mucosal surfaces.

The study of (Rubio et al., 1998) showed that E. coli counts in both small and large intestinal sections decreased with respect to control values in broiler fed diets containing lupin meal. On the basis of these results, a part of this investigation was conducted to study the effect of the current treatments on total bacterial and E.coli counts in the intestine of growing quails fed corn soybean based diet supplemented with probiotics.

The results of total bacterial and E.coli count observed in the current investigation tended to decrease with Organic Green Culture followed by Samu Biogen and Xylam. These results are in harmony with those observed by Jin et al., (1996) and Jin et al., (2000) who reported that propiotics containing Lactobacillus strains have the ability to adhere strongly to the intestinal epithelium of chicken, antagonize and competitively exclude some pathogenic bacteria in vitro (Jin et al., 1998). It has been known that lactic acid intestinal bacteria inhibit pathogenic bacteria especially Escherichia coli which is considered an important pathogen causing bloody diarrhea (hemorrhagic colitis) and renal failure (hemolytic uremic syndrome) as reported by Salmon et al., (1989).Salem et al.(2004) indicated that probiotics had a positive effect on lactic acid produce by intestinal bacteria activities and it could improve their inhibition to un-friendly bacteria such as Escherichia coli .Qin et al. (1995) sustained that lactobacilli protect against potentially harmful bacteria such as salmonella and aid the digestive process.Properly selected cultures of probiotics, such as lactobacillus species, can overcome those Lactobacilli found in the natural flora of the birds and exert inhibitory action towards salmonella in the intestinal tract of chickens. The positive effect of propiotics may be in part due to corn and soybean meal content. Soybean contains very high proportion of pectic polysaccharides (galacturonans and associated arabinogalactans) as the main contributing polysaccharides as well as water soluble carbohydrates (WSC) which account for $10 \%$ by the weight of the bean. Corn also has a cellular endosperm like to that of wheat contains branched arabioxylans mixed with glucan, small amount of cellulose and xylans which are quite labile and probably highly susceptible to fermentative break-down (Carre et al., 1989). This suggests that corn - soybean meal diet, would offer some saccharolytic microflora species colonizing in the gut a suitable substrate to grow. It has been shown in vitro that xylo and fructo-oligosachaarides are converted to acids at the highest rate by Lactobacilli and not used by most clostridia and E. coli among others.Tannock (1990) mentioned that broiler chicks are peculiar in that they contain high numbers of lactobacilli particularly in the upper parts of their intestinal tract. This results from the

Fayoum J. Agric. Res. \& Dev., Vol. 21, No. 2, July, 2007 
stratified structure of the non-secretorial mucosa in their crop which provides the appropriate conditions for these species to grow. Its action for, by encouraging the growth of native species of Lactobacilli at the expense of the clostridia, a degree of nutritional enhancement could still follow an improvement that is magnified by the concurrent ingestion of Lactobacillus.

\section{CONCLUSION}

It could be concluded that the growth promoting effect of Organic Green Culture, Samu Biogen and Xylam could be attributed to the beneficial components that may exist in the commercial products either enzymatic or probiotics. Both components may act synergistically to increase growth performance and immunity.

\section{REFERENCES}

Adeola, O., and M.R. Bedford. 2004. Exogenous dietary xylanase ameliorates viscosity-induced anti-nutritional effects in wheat-based diets for White Pekin ducks (Anas platyrinchos domesticus). Br. J. Nutr. 92:87-94.

Ahmad, I., 2004. Effect of probiotic (protexin) on the growth of broilers with special reference to the small intestinal crypt cells proliferation. $\mathrm{PhD}$ Thesis. Centre of Biotechnology, Univ. of Peshawar Pakistan.

Ahmad, I., 2006. Effect of probiotics on broilers performance. Int. J. Poult. Sci. 6: 593- 597.

Ali, M.A., 1999. Effect of probiotics addition to broiler rations on performance and some blood constituents. Egypt. Poult. Sci.19 (1) $161-177$.

Almirall M. and Esteve- Garica E., 1994. Rate of passage of barley diets Chromium oxide, influence of age and poultry strain and effect of $\beta$ glucanase supplementation. Poult. Sci. 73: 1433- 1440.

Annison, G., 1991. Relationship between the levels of soluble nonstarch polysaccharides and the apparent metabolizable energy of wheat assayed in broiler chickens. J. Agric. Food Chem. 39: 1252- 1256.

Annison, G., 1992. Commercial enzyme supplementation of wheat based diets raises ileal glycanase activities and improves apparent metabolizable energy,starch and pentosan digestibilities in broiler chickens. Anim. Feed Sci. and Technol. 38: 105- 121.

Armstrong, W.D. and Carr, C.W. (1964). Physiological Chemistry: Laboratory Directions. 3rd ed., Bunges Publishing Co., Minneopolis Minnesota, U.S.A.

Beachey, E.H., 1980. Bacterial adherence. Chapmana and Hall publishers, London. UK.

Bedford, M.R., and H.L. Classen, 1992. Reduction of intestinal viscosity through manipulation of dietary rye and pentosanase concentration is effected through changes in the carbohydrate composition of the intestinal aqueous phase and results in improved growth rate and food conversion efficiency of broiler chicks. J. Nutr. 122: 560- 569.

Bedford, M.R., and J., Apajalahti, 2002. Microbial interactions in response to exogenous enzyme utilization. Enzyme in Farm Animal Nutrition. 299314. CABI Publishing, London. UK.

Fayoum J. Agric. Res. \& Dev., Vol. 21, No. 2, July, 2007 
Bhat, M.K., and G.P. Hazlewood, 2001. Enzymology and other characteristics of cellulases and xylanase. Enzyme in Farm Animal Nutrition, 11- 60. CABI Publishing, London. UK.

Bogin, E., and P. Keller, 1987. Application of clinical biochemistry to medically relevant animal models and standarization and quality control in animal biochemistry. J. Clin. Chem. Clin. Biochem. 25: 873 -878 .

Brenes, A., M. Smith, W. Guenter, and R.R. Marquardt, 1993. Effect of enzyme supplementation on the performance and digestive tract size of broiler chickens fed wheat and barley based diets. Poult. Sci., 72:17311739.

Brown, I. 1996. Complex carbohydrates and resistant starch. Nutr. Rev. 54: S115- S119.

Caldwell D.J., H.D. Danforth, B.C. Morris, K.A. Ameiss, and A.P. McElroy, 2004. Participation of the intestinal epithelium and mast cells in local mucosal immune responses in commercial poultry. Poult. Sci. 83:591-599.

Carre, B., L. Derouet, B. Leclercq, 1989. The digestibility of cell-wall polysaccharides from wheat (bran or whole grain), soyabean meal, and white lupin meal in cockerels and Muscovy ducks. Poult. Sci. 68: 623633.

Choct, M., R.J. Hughes, J. Wang, M.R. Bedford, A.J. Morgan, and G. Annison, 1995. Feed enzymes eliminate the anti-nutritive effect by NSP and modify fermentation in broilers. Proc. Aust. Poult. Sci. Symp. 7, PP. $121-125$.

Choct, M., 2006. Enzymes for the feed industry, past, present and future. World's Poult.Sci. 62: 5- 15.

Cowan, W.D., 1995. The relevance of intestinal viscosity on performance of practical broiler diets. Proc. Aust. Poult. Sci. Symp. 7: 116- 120.

Cowieson, A.J., 2005. Factors that affect the nutritional value of maize for broilers. Anim. Feed Sci.and Technol. 119: 293- 305.

Cruickshank, R.; Duguid, J.P.; Marmion, B.P. and Swain, R.H.A. (1977). Medical Microbiology. Vol.2, the practice of Medical Microbiology. $12^{\text {th }}$ Ed., Churchill Livingstone, Edinburgh, London. UK.

Cummings, J.H., 1981. Dietary fibre. British Medical Bulletin, 37: 65- 70.

Dalloul, R.A., H.S. Lillehoj, T.A. Shellem, and J.A. Doerr, 2003. Enhanced mucosal immunity against eimeria acervulina in broilers fed a lactobacillus-based probiotic. Poult. Sci. 82:62-66.

Duncan, D.B., 1955. Multiple range and multiple F tests. Biometrics, 11: 142.

El-Husseiny, O.M, A.A. Ghazalah, H.M. Fayek, and S.M. Abou ElWafa, 1995. Enzyme preparations, growth promoters and rumen contents in broiler diets. Poult. Sci., 74: 205- 232.

Fincher, G.B. and B.A. Stone, 1986. Cell walls and their components in cereal grain technology. In: Pomerans, Y. (Ed.), Advances in Cereal Science and Technology. Vol. 8. American Association of Cereal Chemists, St. Paul, MN. pp: 207-295.

Flores, M.P., J.I.R. Castanon, and J.M. McNab, 1994. Effect of enzyme supplementation of wheat and triticale based diets for broiler. Anim. Feed Sci.and Technol. 49:237- 243.

Fayoum J. Agric. Res. \& Dev., Vol. 21, No. 2, July, 2007 
Friesen, O.D., W. Guenter, B.A. Rotter,and R. R. Marquardt, 1991. The effects of enzyme supplementation on the nutritive value of rye grain (scale cereale) for the young broiler chick. Poult. Sci., 70: 2501- 2508.

Frolich, W. 1990. Chelating properties of fiber and phytate. Pages 83-93 in New Developments in Dietary Fiber: Physioligical, Physiocochemical and Analytical Aspects. I. Furda and C. J. Brine, ed. Premium Press, NY. USA.

Fuller, R., 1997. Probietics 2.Application and practical aspects. Chapman and Hall publishers, London. UK.

Ghazalah, A.A., A.H., Abd El-Gawad, M.S., Soliman, and A.W. Youssef, 2005. Effect of enzyme preparation on performance of broilers fed corn- soybean meal based diets. Egypt. Poult. Sci. 25: 295- 316.

Hashish, S.M., and A.A. El- Ghamry, 1998. Substitution of yellow corn by sorghum in layer ration and the effect of methionine and kemzyme supplementation on hen performance and egg quality. Egypt. Poult. Sci. 18: 241- 253.

Havenaar, R. and S. Spanhaak, 1994. Probiotics from an immunological point of view. Curr. Opin.Biotechnol. 5: 320-325.

Heckert, R.A.; Estevez, E. Russek-Cohen and R. Pettit-Riley, 2002. Effects of density and perch availability on the immune status of broilers. Poult. Sci., 81:451-457.

Hong, D., H. Burrows, and O. Adeola, 2002. Addition of enzymes to starter and grower diets for ducks. Poult. Sci. 81: 1842- 1849.

Huisman, M.M.H., H.A. Schols, and A.G.J. Voragen. 2000. Glucoronoarabinoxylans from maize kernel cell wall are more complex than those from sorghum kernel cell walls. Carbohydr. Polym. 43: 269279.

Jin, L.Z., Y.W.Ho, N.Abdullah, and S. Jalaludin. 1996. Influence of dried Bacillus subtilis and Lactobacilli cultures on intestinal microflora and performance in broilers. Asian-australas. J. Anim. Sci. 9:397-404.

Jin, L.Z., Y.W. Ho, N. Abdullah, and S. Jalaludin. 1998. Growth performance, intestinal microbial populations, and serum cholesterol of broilers fed diets containing Lactobacillus cultures. Poult. Sci. 77:1259-1265.

Jin, L.Z., Y.W.Ho, N. Abdulla, and S. Jalaludin. 2000. Digestive and bacterial enzyme activities in broilers fed diets supplemented with Lactobacillus cultures. Poult. Sci. 79:886-891.

Klasing, K.C., 1998. Avian macrophages: regulators of local and systemic immune responses. Poul. Sci.77: 983-989.

Lan, P.T., T.L. Binh and Y. Benno, 2003. Impact of two probiotics lactobacillus strains feeding on fecal Lactobacillus strains feeding on fecal Lactobacillus, and weight gains in chickens. J. Gen. Appl. Microbiol., 49:29-36.

Lee, S.H., H.S. Lillehoj, 1, R.A. Dalloul, D.W. Park, Y.H. Hong, and J.J. Lin, 2007. Influence of pediococcus-based probiotic on coccidiosis in broiler chickens. Poult Sci 86: 63-66.

Lazaro, R., M.A. Latorre, P. Medel, M. Gracia, and G. G. Mateos, 2004. Feeding regimen and enzyme supplementation to rye-based diets for broilers. Poult.Sci. 83:152-160.

Leeson, S., L.J. Caston, and J. D. Summers, 1996. Broiler response to energy and protein dilulion in the finisher diet. Poult. Sci. 75:522-528.

Fayoum J. Agric. Res. \& Dev., Vol. 21, No. 2, July, 2007 
Lillehoj, H.S., and J.M. Trout. 1993. Coccidia: A review of recent advances on immunity and vaccine development. Avian Pathol.22:3-31.

Mahagna, M., I. Nir, M. Larbier, and Z. Nitsan. 1995. Effect of age and exogenous amylase and protease on development of the digestive tract, pancreatic enzyme activities and digestibility of nutrients in young meat-type chicks. Reprod. Nutr. Dev. 35:201-212.

Majiyabe, K.A. and Hitchner, S.B. (1977). Antibody response to strain combination of New Castle Disease Virus as measured by hemagglutination inhibition. Avian Diseases 21: 567-584.

Malathi, V., and G. Devegowda, 2001. In vitro evaluation of nonstarch polysaccharide digestibility of feed ingredients by enzymes. Poult. Sci. 80: 302-305.

Marsman, G.J., H. Gruppen, A.F. Von der poel, R.P. Kwakkel, M.W. Verstegen and A.G. Voragen, 1997. The effect of thermal processing and enzyme treatments of soybean meal on growth performance, ileal nutrient digestibilies and chime characteristics in broiler chicks. Poult. Sci., 76:864-872.

Morris, B.C., H.D. Danforth, D.J. Caldwell, F.W. Pierson, and A.P. McElroy, 2004. Intestinal mucosal mast cell immune response and pathogenesis of two eimeria acervulina isolates in broiler chickens. Poult. Sci. 83:1667-1674.

Nahashon, S.N.; H.S. Nakaue and L.W. Mirosh. 1994. Production variables and nutrient retention in Single Comb White Leghorn laying pullets fed diets supplemented with direct fed microbials. Poult. Sci. 73:16991711.

National Reasearch Council (NRC), 1994. Nutrient requirements of poultry, 9th ed. National Academy Press, Washington, D. C., USA.

Olukosi, O.A.; A.J. Cowieson, and O. Adeola, 2007. Age-related influence of a cocktail of xylanase, amylase, and protease or phytase individually or in combination in broilers. Poult. Sci. 86:77-86.

Onyango, E.M.; M.R. Bedford, and O. Adeola. 2005. Efficacy of an evolved Escherichia coli phytase in diets of broiler chicks. Poult. Sci. 84:248-255.

Palander, S.; M. Näsi, and S. Järvinen. 2005. Effect of age of growing turkeys on digesta viscosity and nutrient digestibility of maize, barely and oats fed as such or with enzyme supplementation. Arch. Anim. Nutr. 59:191-203.

Parkkonen, T.; A., W. Tervila, and M.A. Hopeakoski-Nurminen. 1997. microstructure following in vitro digestion. Acta Agric. Scand. B Soil Plant Sci. 47:43-47.

Pope, C.R. 1991. Pathology of lymphoid organs with emphasis on immunosuppression. Vet. Immunol. Immunopathol. 30:31-44.

Preston, C.M.; K.J. McCracken and M.R. Bedford, 2001. Effect of wheat content, fat source and enzyme supplementation on diet metabolizability and broiler performance. Br. Poult. Sci., 42: 625-632.

Qin, Z. R.; T. Fukata, E. Baba and A. Arakawa, 1995. Effect of lactose and Lactobacillus acidophilus on the colonization of salmonella enteritidis in chicks currently infected with Eimeria Tenilla. Avian Diseases, 39: 548- 553.

Fayoum J. Agric. Res. \& Dev., Vol. 21, No. 2, July, 2007 
Rubio, L.A.; A. Brenes, I. Setien; G. Dela Asuncion, N-Duran, and T. Cutuli, 1998. Lactobacilli counts. In crop, ileum and caecum of growing broiler chickens fed on practical diets containing whole or dehulled sweet lupin (lupinus angustifolius) seed meal. Br. Poult. Sci. 39:354-359.

Salem, A.Z.M.; M.M.El-Adawy; M.Z.M. Salem and A.A.Hassan, 2004. Effect of probiotics feed as additives on the activity of isolated and characterized lactic acid intestinal bacteria to inhibit Escherichia coli10 in sheep. Egypt.J. of Nutr. and Feeds 7: 167-184.

Salih, M. E.; H. L. Classen, and G. L. Campbell, 1991. Response of chickens fed on hull-less barley to dietary $\beta$-glucanase at different ages. Anim. Feed Sci.and Technol. 33:139-149.

Saulnier, L.; J. Vigouroux, and J.F. Thibault, 1995. Isolation and partial characterisation of feruloylated oligosaccharides from maize bran. Carbohydr. Res. 272: 241-253.

Salmon, R.L.; I.D. Farrell; J.G.P. Hutchison; D.J. Coleman; R. J. Gross; N.K. Fry; B. Rowe and S.R. Palmer (1989). A christening party outbreak of hemorrhagic colitis and hemolytic uremic syndrome associated with Escherichia coli O157:H7. Epidemiol. Infect. 103:249254.

SAS Institute, 1996. SAS User's Guide: Statistics version 12 ed. SAS Institute Inc., Cary, NC. USA.

Schalm, D.W., Jain, N.C., and E.J. Caroll, 1975. Veterinary Hematology. 3rd ed. Lea and Febiger, PA. USA.

Scholtyssek, V.S. and R. Knorr, 1987. Effect of cellulolytic enzyme mixture in the broiler feed with triticale and rye. Arch. Geflugelkd, 51:10-15.

Silva, E. N.; A.S. Teixeira; C. Bertechini; L. Ferreiva and B. G. Ventura, 2000. Cienciae e Agrotecnologia. Ed. Especial. 24:224-232.

Sinlae, M., and M. Choct, 2000. Xylanase supplementation affects the gut microflora of broilers. Austr. Poult. Symp. 12:209.

Stern, N. J.; N. A. Cox; J. S. Bailey; M. E. Berrang and M. T. Musgrove. 2001. Comparison of mucosal competitive exclusion and competitive exclusion treatment to reduce Salmonella and Campylobacter spp. colonization in broiler chickens. Poult. Sci. 80:156-160.

Tannock, G.W., 1990. The microecology of Lactobacilli inhabiting the gastrointestinal tract. Advances in Microbia Ecology, 11:147-171.

Tellez, G.; Dean, C.E.; Corrier, D.E.; Deloach, J.R.; Jaeger, L. and Hargis, B.M. (1993). Effect of dietary lactose on cecal morphology ,pH,organic acids and Salmonella enteritidis organ invasion in Lenghorn chicks. Poultry Sci.,72:636-642.

Troche, C.; X. Sun; A.P. McElroy; J. Remus, and C.L. Novak, 2007. Supplementation of avizyme 1502 to corn-soybean meal-wheat diets fed to turkey Tom poults:The first fifty-six day of age.Poult. Sci. 86: 496-502.

Veldman, A. and H.V. Vabl, 1994. Xylanase in broiler diets with differences in characteristics and content of wheat. Br. Poult. Sci., 35:537-550.

Wu, Y.B.; V. Ravidran; D.G. Thomas; M.J. Birties and W.H. Hendricks. 2004. Influence of phytase and xylanase, individually or in combination on performance, apparent metabolisable energy, digestive tract measurements and gut morphology in broilers fed wheat-based diets containing adequate level of phosphorus. Br. Poult. Sci. 45:76-84.

Fayoum J. Agric. Res. \& Dev., Vol. 21, No. 2, July, 2007 
PRACTICAL ASPECTS OF ENZYME-PROBIOTICS................

Yonemochi, C.; H. Fujisaki, and H. Takagi, 2003. Effects of amino acid, enzyme mixture and phytase added to low protein and low phosphorus diet on performance and excretion of nitrogen and phosphorus in broiler. Poultry Sci. 82:114-120.

Zyla, K.; D.R. Ledoux; M. Kujawski and T. L. Veum. 1996. The efficacy of an enzymic cocktail and a fungal mycelium in dephosphorylating corn-SBM-based feeds fed to growing turkey. Poult. Sci. 75:381-387.

المظاهر التطبيقية لإضافه خليط من الإنزيمات ومعضدات النمو الحيويه إلى علائق السمان

$$
\text { عادل السيد أبو زيد }
$$

قسم الانتاج الحيوانى ـ كلية الزراعة ـ جامعة طنطا - مصر

تهدف هذه الاراسة إلى بيان نأثير إضافة كل من الأنزيمات ومعضدات النمو الحيوية الى العلائق

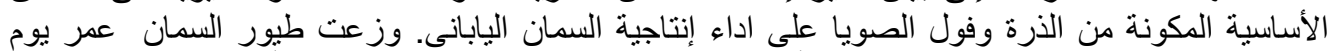

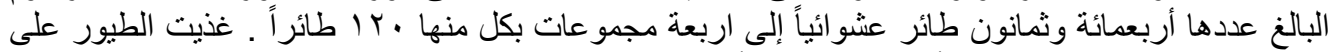

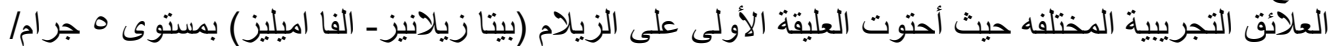

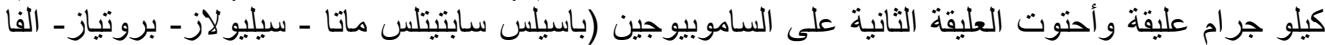

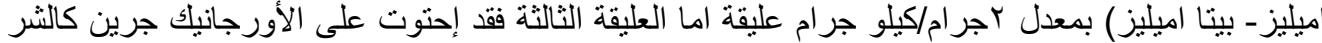

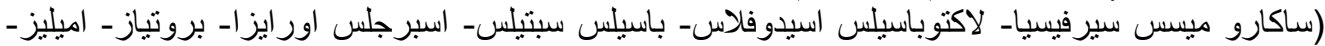

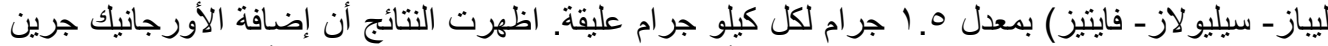

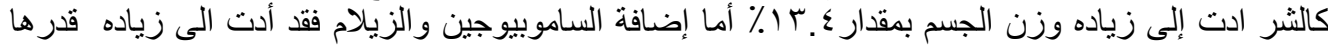

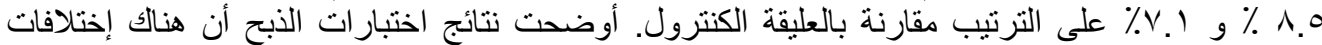

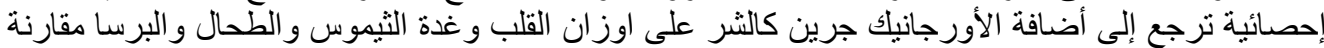

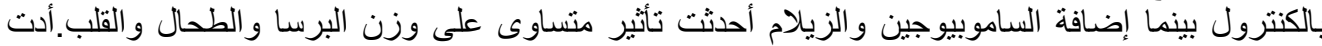

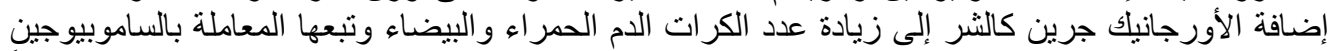

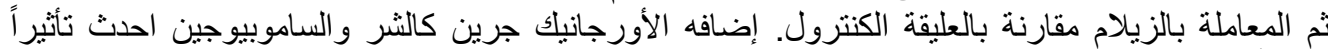

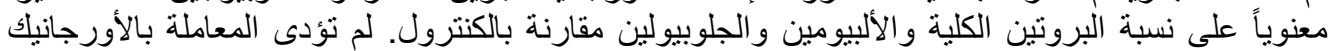

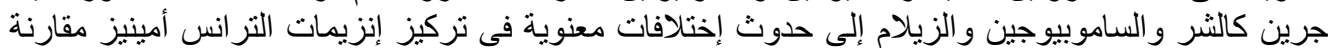

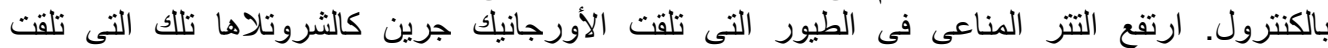

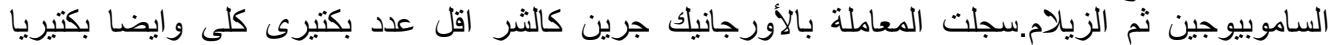

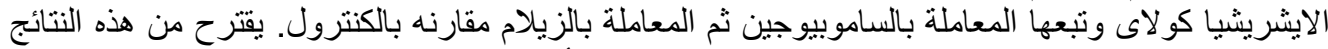

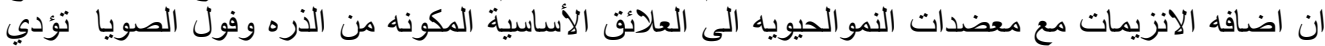
الي حدوث تحسن في الكفاءة الإنتاجية لطيور السمان.

Fayoum J. Agric. Res. \& Dev., Vol. 21, No. 2, July, 2007 